\title{
Molecular Effects of Xylella fastidiosa and Drought Combined Stress in Olive Trees
}

\author{
Mariarosaria De Pascali ${ }^{1}$, Marzia Vergine ${ }^{1, * \mathbb{C}}$, Erika Sabella $^{1}$, Alessio Aprile ${ }^{1}$, \\ Eliana Nutricati ${ }^{1}$, Francesca Nicolì ${ }^{1}{ }^{1}$, Ilaria Buja ${ }^{2}$, Carmine Negro ${ }^{1}{ }^{\circledR}$, Antonio Miceli ${ }^{1}$, \\ Patrizia Rampino ${ }^{1}$, Luigi De Bellis ${ }^{1}$ (D) and Andrea Luvisi ${ }^{1}$ (D) \\ 1 Department of Biological and Environmental Sciences and Technologies, University of Salento, 73100 Lecce, \\ Italy; mariarosaria.depascali@unisalento.it (M.D.P.); erika.sabella@unisalento.it (E.S.); \\ alessio.aprile@unisalento.it (A.A.); eliana.nutricati@unisalento.it (E.N.); francesca.nicoli@unisalento.it (F.N.); \\ carmine.negro@unisalento.it (C.N.); antonio.miceli@unisalento.it (A.M.); \\ patrizia.rampino@unisalento.it (P.R.); luigi.debellis@unisalento.it (L.D.B.); andrea.luvisi@unisalento.it (A.L.) \\ 2 Department of Mathematics and Physics "Ennio De Giorgi", University of Salento, 73100 Lecce, Italy; \\ ilaria.buja@unisalento.it \\ * Correspondence: marzia.vergine@unisalento.it
}

Received: 30 July 2019; Accepted: 20 October 2019; Published: 23 October 2019

\begin{abstract}
Due to global climate change, complex combinations of stresses are expected to occur, among which the interaction between pathogens and drought stress may have a significant effect on growth and yield. In this study, the Xylella fastidiosa (Xf)-resistant cultivar Leccino and the susceptible one Cellina di Nardò were subjected to (a) individual drought stress, (b) Xf infection and (c) combination of both stress conditions. Here we report the physiological response to stresses in water content in leaves and the modulation in the expression level of seven genes responsive to plant water status and pathogen infection. In Xf-resistant plants, higher expression levels are reported for genes belonging to ROS-scavenging systems and for genes involved in pathogen stress (pathogenesis-related, $P R$, and leucine-rich repeat genes, $L R R-R L K)$. However, $P R$ and $L R R-R L K$ were not further induced by water deficit. Interestingly, the genes related to drought response (aquaporin, PIP2.1, dehydration responsive element binding, DREB, and dehydrin, DHN), which induction was higher in Cellina di Nardò compared to Leccino during drought stress, was poorly induced in $X f$-susceptible plants when $X f$ occur. Conversely, $D H N$ was induced by $X f$ presence in Leccino. These results were consistent with observations on water content. Indeed, response was similar in Leccino regardless kind of stress or combination, whereas a strong reduction was observed in $X f$-susceptible plants infected by $X f$ or in presence of combined stresses. Thus, the reported findings indicate that resistance of Leccino to $X f$ could be linked to its lower resistance to water stress, probably leading to the activation of alternative defense pathways that support the plant in $X f$ response.
\end{abstract}

Keywords: abiotic-biotic stress; combined stress; water deficit; plant disease; pathogen tolerance

\section{Introduction}

In field conditions, plants are exposed to different environmental stresses. The molecular mechanisms underlying stress tolerance have been intensely studied [1-3] and the molecular mechanisms of tolerance in response to individual stresses have been explored [4-7]. However, studies on their combined effect are less common, despite being strongly associated and having a severe impact on growth and productivity [8-10]. When plants are exposed to different stress combinations, a variety of interacting signal transduction pathways are induced [11]. The interaction between these pathways can either 
be neutral, additive, synergistic or may lead to novel unpredictable responses [12,13]. In most cases, plant responses to combined stresses deviate from responses to the individual stresses $[14,15]$. Among different stress combinations that occur in field conditions, the combination of drought and pathogen stress is a relevant topic, since drought stress can positively or negatively affect pathogen infection [16]. In some studies, drought stress increases the susceptibility to bacterial pathogens [17], conversely, in other studies, drought stress has also been shown to enhance the tolerance toward bacteria pathogens $[18,19]$. Host resistance and water deficit stress tolerance are controlled by complex mechanisms and share several basal plant defense strategies. The stresses induce the modulation of the enzymatic antioxidant system, involving many enzymes, such as superoxide dismutase (SOD), catalase (CAT), and peroxidases (POX) including ascorbate peroxidase (APX), providing a highly efficient system for maintaining reactive oxygen species (ROS) homeostasis in various sites of plant cell [20]. Furthermore, numerous regulatory and/or protective proteins involved in stresses response such as aquaporins (AQPs), dehydration responsive element binding (DREB), and dehydrin proteins (DHNs) confer outstanding ability to resist drought [21], while the most commonly induced proteins during plant pathogens defense mechanisms are pathogenesis-related (PR) protein and leucine-rich repeat receptor like protein kinase (LRR-RLK).

At the end of 2013 a quarantine plant pathogen was recognized in Southern Italy (Salento peninsula, located in the Apulia region), associated to a previously unknown disease on olive trees (Olea europaea L.) which cause a leaf scorch, a rapid decline and the death of trees (the so-called "Olive Quick Decline Syndrome", OQDS) [22]. These symptoms are particularly severe on plants of the $c v$ Cellina di Nardò (hereafter Cellina), whereas $c v$ Leccino seems weakly attacked [23,24]. The evidence and the following research studies indicated a connection with the bacterium Xylella fastidiosa subsp. pauca 'De Donno' (Xf) [25]. The bacterium exists as an endophytic commensal and spreads from the site of infection to colonize the xylem, whereas the subsequent vessel occlusion [26] induces plants to drought stress conditions and symptom development, which may be worsened by abiotic stress (e.g., the leaf scorch, which characterize the symptom of OQDS before wilting of branch, reduce the performance of photosynthetic apparatus, which may be further affected by water deficit in soil [27]. Furthermore, the studies about the potential distribution of $\mathrm{Xf}$ in current and future climate conditions forecast the presence of the bacterium in many regions of the Mediterranean area [28,29], one the most vulnerable area in the world to the impacts of global warming [30]. In this contest, the combined effect of a xylem-affecting pathogen and drought-stress highlights new challenges for plant management and protection in territories threatened by Xf. Thus, the knowledge of drought-related transcriptional mechanisms involved in contrasting a drought-inducer pathogen in water-deficit conditions should drive the search for resistant plants, which represent the most promising strategy to hinder the disease.

In this paper, we investigate the host's transcriptional responses to $X f$ infection and drought in two cvs, Cellina ( $X f$-susceptible) and Leccino ( $X f$-resistant) under individual stress (drought or pathogen stress) and combined stress in field conditions, evaluating the change in relative water content and expression of genes coding for enzymes related to ROS scavenging activity, water deficit and pathogen stress response.

\section{Results}

\subsection{Estimation of Water and Proline Content and Enzyme Assays}

The physiological characterization of the two cvs analyzed in their response to drought, pathogen, and combined stresses were performed by measurement of relative water content (RWC) (Figure 1). The RWCs of control plants were not significantly different among the analyzed plants (RWC $~ 94 \%$ for both cvs). In samples subjected to drought stress, RWCs measured were lower in Leccino (with a value of about $63 \%$ ) compared to Cellina (with a higher value of about $85 \%$ ), indicating a better water status under absence of irrigation $(p<0.0001)$. This result is consistent with a commonly recognized tolerance to water stress of Cellina compared to Leccino. Conversely, in plants subjected to pathogen stress, 
the decrease of RWC value was more drastic in Cellina compared to Leccino. This behavior could be linked to the different impacts on vascular system caused by the pathogen in $c v X f$-susceptible $\left(C_{t} 24-27\right)$ compared to resistant one $\left(C_{t} 28-30\right)$. However, our findings indicate that the RWC in $X f$-positive Leccino samples was similar to that observed in drought stress $(\sim 65 \%)$, indicating a mild effect of the pathogen on water content. Conversely, a sharp decline was observed in Cellina samples ( 41\%).

Moreover, in the drought/pathogen combined stress, the $c v$ Cellina registered a further significant reduction in RWC value (reaching about $29 \%$ of RWC), while Leccino samples showed the similar performance compared to individual stresses $(\sim 60 \%)$, confirming how the pathogen presence is not more suffered than drought by this $c v$.

Cellina and Leccino cos have shown a low constitutive content of free proline (Figure 2). On the contrary, the proline content in the leaves of both cos was significantly higher in the stressed plants.

In particular, the Cellina samples subjected to drought stress showed significantly more proline content $\left(3.05 \mu \mathrm{mol} \mathrm{g} \mathrm{FW}{ }^{-1}\right)$ than Leccino $\left(1.96 \mu \mathrm{mol} \mathrm{g} \mathrm{FW}^{-1}\right)$. Moreover, in plants subjected to pathogen stress, the proline content increased in Leccino $\left(4.61 \mu \mathrm{mol} \mathrm{g} \mathrm{FW}{ }^{-1}\right)$ and decreased in Cellina $\left(1.98 \mu \mathrm{mol} \mathrm{g} \mathrm{FW}^{-1}\right)$ compared to drought stress.

In drought/pathogen combined stress the proline content in Cellina $\left(3.06 \mu \mathrm{mol} \mathrm{g} \mathrm{FW}{ }^{-1}\right)$ achieve the same level registered in drought stress, whereas in Leccino $\left(6.22 \mu \mathrm{mol} \mathrm{g} \mathrm{FW}^{-1}\right)$ have been observed an additive effect of the two individual stresses.

Furthermore, the activities of antioxidant enzymes showed a significant increase in values in both cultivars under individual and combined stresses compared with control plants (Table 1). Under all stress conditions considered, the enzyme activity of APX, CAT, and SOD showed a higher level in Leccino compared to Cellina. In particular, the highest enzyme activity was measured in Leccino for $\operatorname{APX}\left(12.30 \mathrm{EU} \mathrm{mg}^{-1}\right)$ and SOD (28.49 $\mathrm{EU} \mathrm{mg}^{-1}$ ) enzymes under combined stresses, while the higher value for CAT activity $\left(15.24 \mathrm{EU} \mathrm{mg}^{-1}\right)$ was reported under sole pathogen stress.

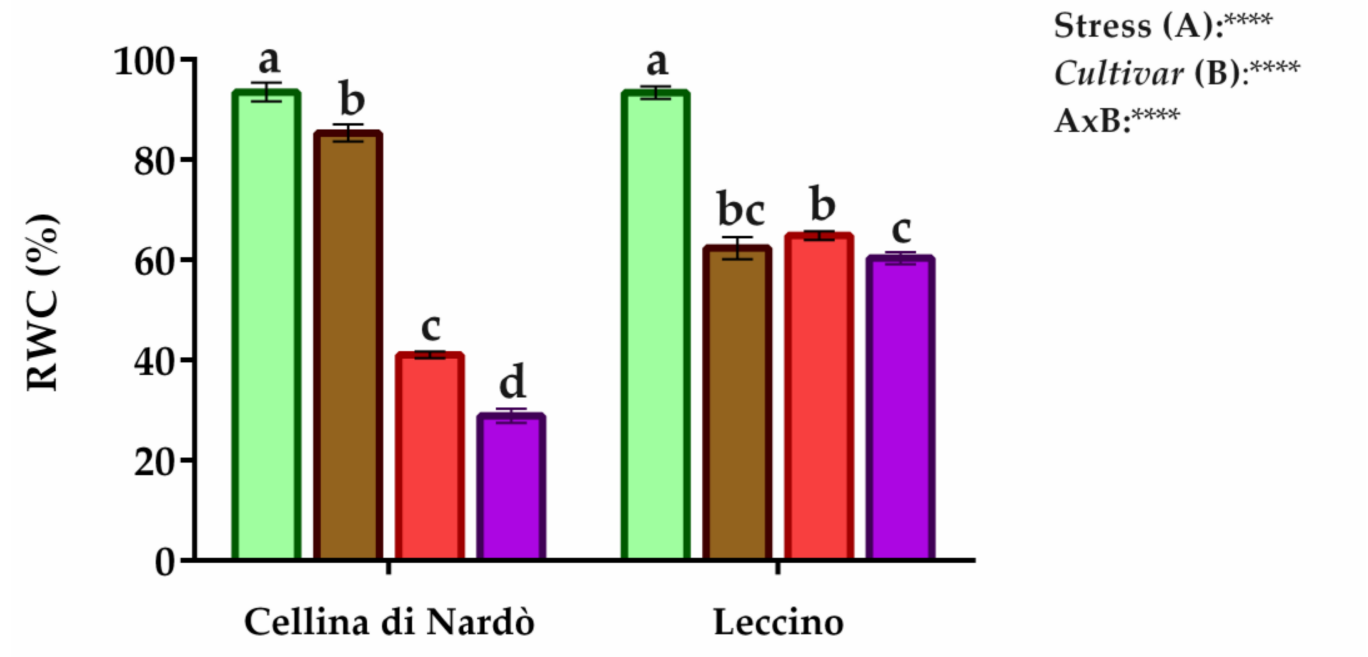

Two-way ANOVA

Stress (A):****

Cultivar (B):****

$\mathrm{AxB}: * * * *$

Cellina di Nardò

Leccino

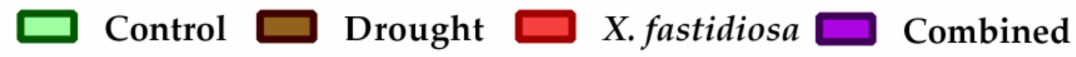

Figure 1. Relative water content (RWC) determined on Cellina di Nardò and Leccino fully expanded leaves subjected to individual and combined stresses (drought and Xylella fastidiosa). Top right Two-way ANOVA results were reported. Different letters correspond to statistically different means. 


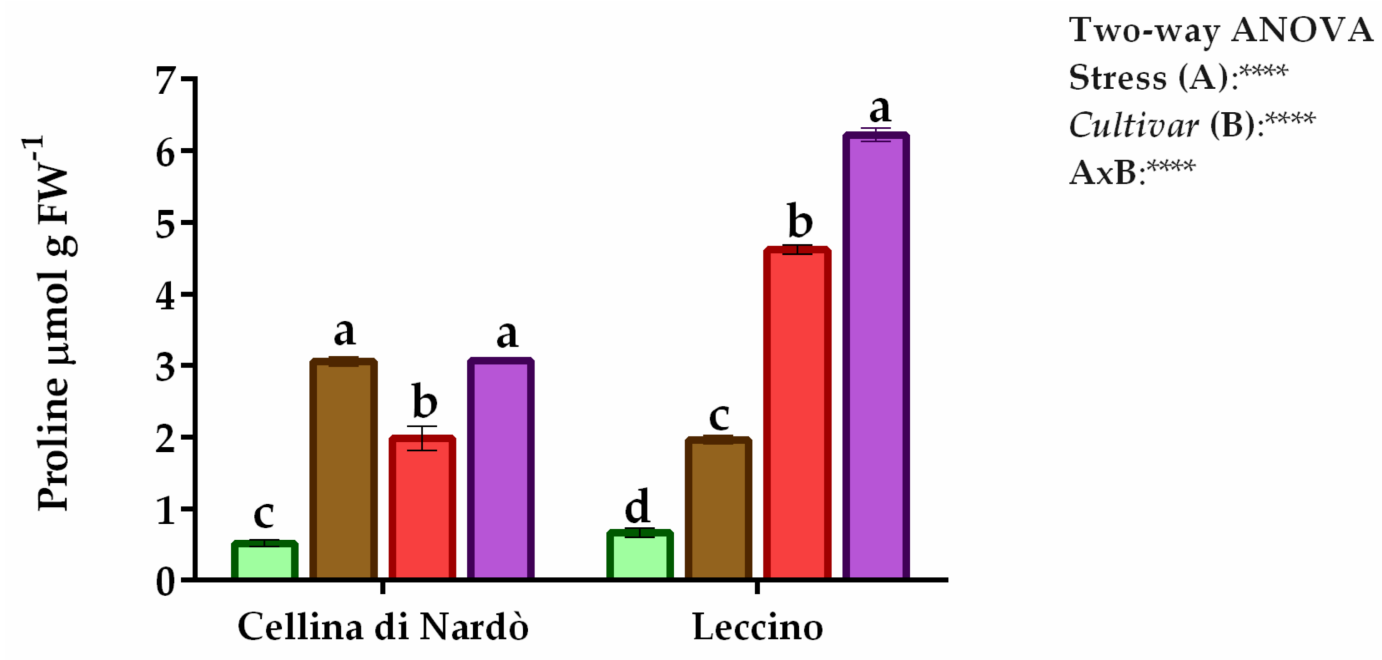

\section{$\square$ Control $\square$ Drought $\square$ X.fastidiosa $\square$ Combined}

Figure 2. Proline content $\left(\mu \mathrm{mol} \mathrm{g} \mathrm{FW}^{-1}\right.$ ) determined on Cellina di Nardò and Leccino leaves subjected to individual and combined stresses (drought and Xylella fastidiosa). Small letter compares the mean of five repetitions (Tukey HSD post hoc test $p \leq 0.05$ ). Top right Two-way ANOVA results were reported.

Table 1. Enzyme activities of ascorbate peroxidase (APX), catalase (CAT), and superoxide dismutase (SOD) determined on Cellina di Nardò and Leccino leaves subjected to individual and combined stresses (drought and Xylella fastidiosa). Data presented are the means \pm SEs $(n=5)$. Within rows, means followed by different low case letters indicate a significant difference $(p \leq 0.05)$ among the cultivars, within columns, means followed by different capital letters indicate a significant difference $(p \leq 0.05)$ among the treatments.

\begin{tabular}{|c|c|c|c|c|c|c|}
\hline \multirow[b]{3}{*}{$\begin{array}{c}\text { Plant } \\
\text { Conditions }\end{array}$} & \multicolumn{6}{|c|}{ Enzyme Activity (EU mg ${ }^{-1}$ Protein) } \\
\hline & \multicolumn{2}{|c|}{ APX } & \multicolumn{2}{|c|}{ CAT } & \multicolumn{2}{|c|}{ SOD } \\
\hline & $\begin{array}{l}\text { Cellina di } \\
\text { Nardò }\end{array}$ & Leccino & $\begin{array}{l}\text { Cellina di } \\
\text { Nardò }\end{array}$ & Leccino & $\begin{array}{l}\text { Cellina di } \\
\text { Nardò }\end{array}$ & Leccino \\
\hline Control & $3.20 \pm 0.03 \mathbf{b}, \mathbf{D}$ & $3.66 \pm 0.12 \mathrm{a}, \mathrm{C}$ & $4.82 \pm 0.23 \mathbf{b}, \mathbf{C}$ & $5.23 \pm 0.10 \mathrm{a}, \mathrm{C}$ & $12.94 \pm 0.14$ a, D & $13.46 \pm 0.42 \mathbf{a}, \mathbf{C}$ \\
\hline Drought & $4.34 \pm 0.17 \mathbf{b}, \mathbf{C}$ & $9.23 \pm 0.03 \mathbf{a}, \mathbf{B}$ & $8.53 \pm 0.43 \mathbf{b}, \mathbf{A}$ & $10.73 \pm 0.22 \mathbf{a}, \mathbf{B}$ & $17.64 \pm 0.57 \mathbf{b}, \mathbf{B}$ & $27.02 \pm 0.99 \mathbf{a}, \mathbf{B}$ \\
\hline X.fastidiosa & $7.22 \pm 0.07 \mathbf{b}, \mathbf{A}$ & $9.27 \pm 0.12 \mathbf{a}, \mathbf{B}$ & $6.53 \pm 0.32 \mathbf{b}, \mathbf{B}$ & $15.24 \pm 0.39 \mathbf{a}, \mathbf{A}$ & $14.08 \pm 0.20 \mathbf{b}, \mathbf{C}$ & $26.52 \pm 0.17$ a, B \\
\hline Combined & $4.66 \pm 0.10 \mathbf{b}, \mathbf{B}$ & $12.30 \pm 0.13 \mathbf{a}, \mathbf{A}$ & $9.10 \pm 0.19 \mathbf{b}, \mathbf{A}$ & $11.03 \pm 0.03 \mathbf{a}, \mathbf{B}$ & $19.33 \pm 0.24 \mathbf{b}, \mathbf{A}$ & $28.49 \pm 0.25 \mathbf{a}, \mathbf{A}$ \\
\hline
\end{tabular}

\subsection{Gene Expression Analysis under Individual and Combined Stresses}

In Cellina (Figure 3), genes related to ROS-scavenging systems were weakly modulated by single or combined stresses. The drought stress causes a limited effect on the expression of the four selected genes, with an increase in CAT and $\mathrm{Cu} / \mathrm{Zn} S O D$ expression (respectively of $\sim 0.65$ and $0.43 \log _{2} \mathrm{FC}$ value). Conversely, the pathogen causes an increase in the expression level of $A P X$, while other genes are just slightly overexpressed. Furthermore, the addition of drought stress seems to hide the $X f$ presence. Regarding genes related to pathogen responses, both are unaffected by drought. Conversely, higher expression was observed for both $L R R-R L K$ and $P R$ when the sole pathogen was present (respectively 1.26 and $0.40 \log _{2}$ FC value). The response was quite unmodified by adding water stress. About the gene related to water stress, aquaporin (PIP2.1) increased the transcript level in all stress conditions. DREB and DHN strongly respond to drought (respectively 1.73 and $2.70 \log _{2} \mathrm{FC}$ value), whereas $X f$ causes a very much lower expression in both genes, which was unmodified by a combination of water stress. 
A

Ascorbate Peroxidase (APX)

Catalase (CAT)
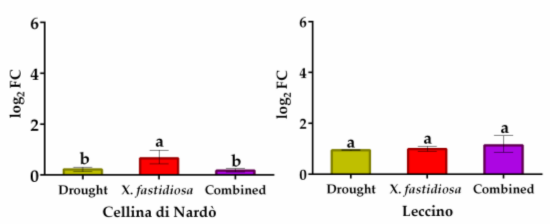

Leccino

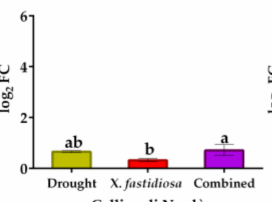

Cellina di Nardo

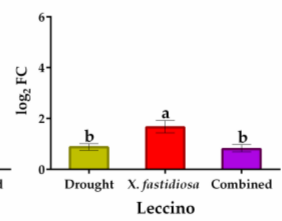

$\mathrm{Cu} / \mathrm{Zn}$ Superoxide dismutase $(\mathrm{Cu} / \mathrm{Zn} \mathrm{SOD})$

Mn Superoxide dismutase (Mn SOD)
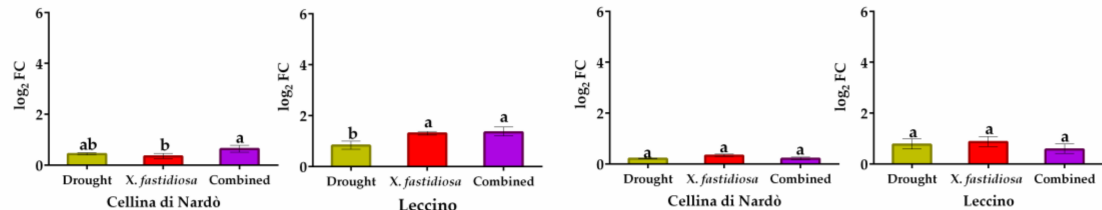

B

Leucine Rich Repeats (LRR-RLK)

Pathogenesis-Related $(P R)$
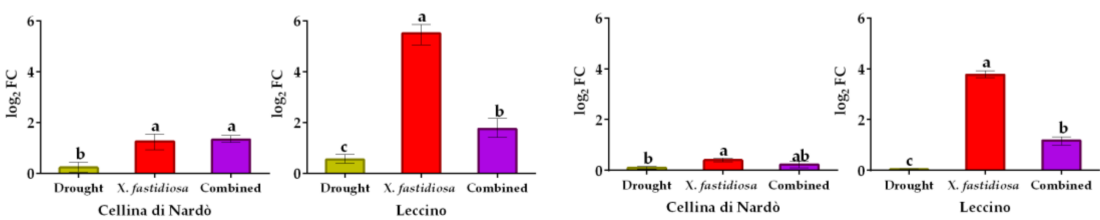

C

Aquaporin (PIP2.1)

Dehydration responsive element biding (DREB)
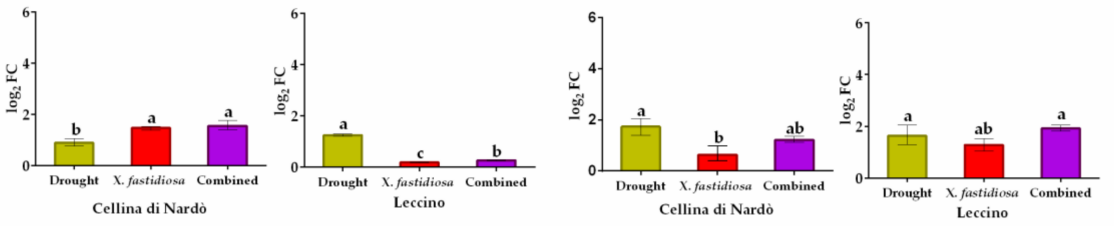

Dehydrin $(D H N)$

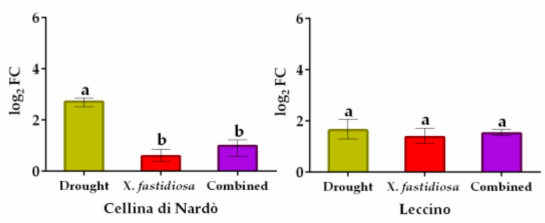

Figure 3. Expression analysis of stress responsive gene in leaves of Cellina di Nardò and Leccino cultivars subjected to stresses: drought, pathogen Xylella fastidiosa and combination of both, expressed as $\log _{2}$ fold change $\left(\log _{2} \mathrm{FC}\right)$. (A) genes related to oxidative stress: superoxide dismutase (Cu/Zn $S O D$ and $M n S O D)$, catalase $(C A T)$, ascorbate peroxidase $(A P X),(\mathbf{B})$ genes related to pathogen stress: leucine rich repeats- receptor like kinase $(L R R-R L K)$ and pathogenesis-related protein 1-like $(P R)$. (C) genes related to drought responses: aquaporin (PIP2.1), dehydration responsive element binding (DREB) and dehydrin $(D H N)$. Statistical analysis was carried out through one-way ANOVA with Tukey-HSD post hoc test. Different letters correspond to statistically different means. 
In Leccino (Figure 3), genes related to ROS-scavenging systems are affected by single or combined stresses. The drought stress causes a similar but significant effect on all selected genes. The pathogen causes significantly higher expression in $C A T$ and $C u / Z n S O D$ expression (respectively of $\sim 1.65$ and $1.30 \log _{2}$ FC value), while the addition of drought stress did not change the expression for CAT gene, in which the effect of pathogen seems hidden. With regard to genes related to pathogen responses, both are unaffected by drought, but we observed a predictable very high expression of $L R R-R L K$ and $P R$ (respectively 5.51 and $3.76 \log _{2} \mathrm{FC}$ value) in $X f$-infected plants. However, the combined presence of water stress strongly reduces the expression of both genes. In relation to the gene related to water stress, PIP2.1 showed low expression levels in all stress conditions considered, while DREB and DHN respond significantly to drought (1.73 and $1.63 \log _{2} \mathrm{FC}$ value), and the gene was also induced regardless of $X f$ presence or combined stresses.

The profile expression of genes was different among cus (Figure 4). Comparing Cellina and Leccino in gene expression level subjected to drought, we observed that genes related to ROS-scavenging systems are higher expressed in $X f$-resistant plants compared to $X f$-susceptible ones. As predictable, any differences were observed on genes related to pathogen response, whereas the expression of $D H N$ was significantly higher in the drought-tolerant Cellina compared to Leccino.

The presence of $X f$ as a stress factor underlines a quite completely different profile of gene expression among the two cos. All genes related to ROS-scavenging systems but APX are higher expressed in Xf-resistant plants compared to $X f$-susceptible ones, while the pathogen induces significantly higher expression of both genes ( $L R R-R L K$ and $P R)$ in Leccino compared to $X f$-susceptible plants. Interestingly, the genes involved in drought stress (DREB and $D H N)$, are more expressed in $X f$-resistant but drought-susceptible plants (Leccino) than in $X f$-susceptible but drought-tolerant ones (Cellina). Conversely, PIP.2.1 is more expressed in Cellina Xf-susceptible but drought resistant plants.

The addition of drought stress to the presence of the pathogen confirm a three out of four higher expressions of genes related to ROS-scavenging systems but CAT, which is similarly expressed in both cultivars, suggesting an additive effect of both stresses on this group of genes. About genes related to pathogen responses, the drought seems to cause a synergic effect on $L R R-R L K$ in Cellina, which expression level becomes comparable to that observed in Leccino. The different behavior among cos of DHN observed in pathogen single stress was confirmed when drought stress was added. 


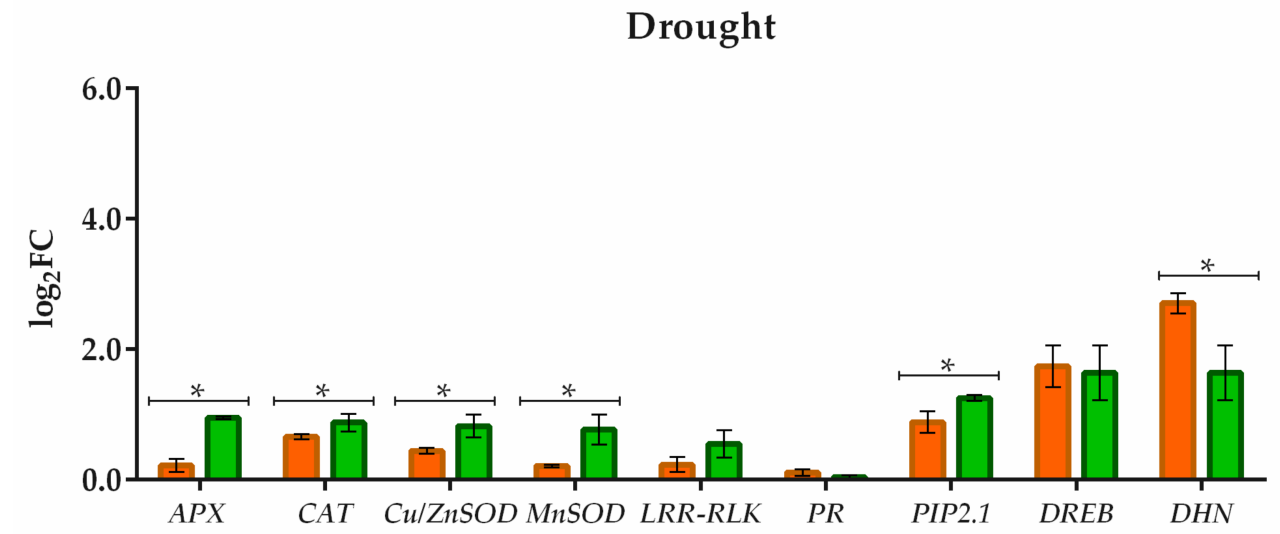

Xylella fastidiosa

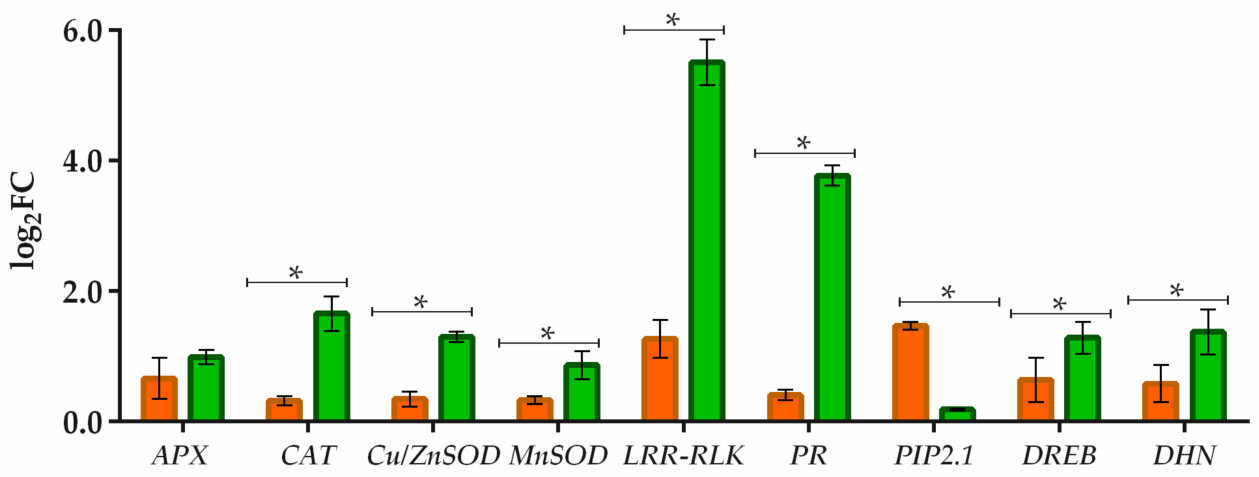

\section{Combined}

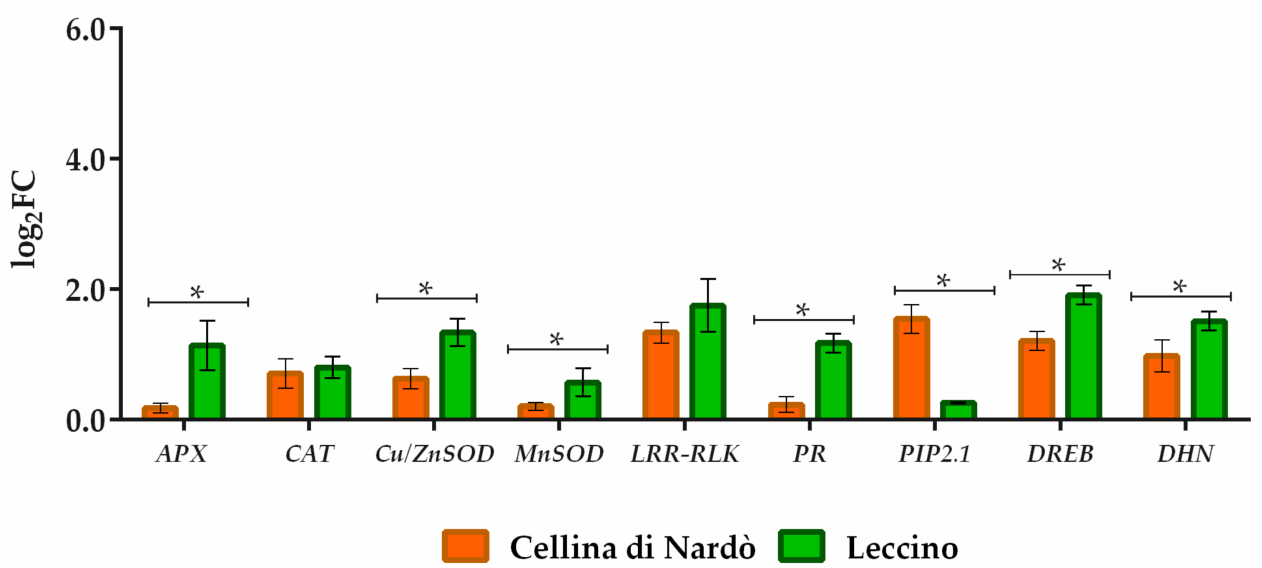

Figure 4. Comparison of Cellina di Nardò and Leccino cultivars in gene expression level subjected to drought, pathogen Xylella fastidiosa and combination of both stresses expressed as $\log _{2}$ fold change $\left(\log _{2} \mathrm{FC}\right)$. The genes related to oxidative stress are: Superoxide dismutase (Cu/Zn SOD and MnSOD), Catalase $(C A T)$, Ascorbate Peroxidase $(A P X)$, the genes related to pathogen stress are: Leucine Rich Repeats $(L R R-R L K)$ and Pathogenesis-Related $(P R)$ and the gene related to drought responses are: Dehydrin $(D H N)$. The statistical analysis was carried out using multiple t-tests (FDR $=5 \%$ ). 


\section{Discussion}

Plants are constantly subjected to both abiotic and biotic stresses and the responses to these stresses are complex and involve numerous physiological, molecular, and cellular adaptations that cause the change in the crop yield and quality. Particularly, the combined occurrence of bacterial pathogen infection and drought may have a great influence on the plant response [31]. There are several common changes in plant responses to drought and pathogens stress: activation of reactive oxygen species scavenging system [32], proline accumulation [33], anthocyanin production [34], lignin deposition [24], reduction of photosynthetic activity $[27,35]$ and alterations in certain other metabolites $[23,36]$.

Goodwin et al. 1988 [37] showed a reduction of stomatal conductance and photosynthesis in symptomatic grapevines infected with Pierce's disease, which is also a common response of water-limited plants [38]. Since $X f$ causes a blockage of the xylem bringing the plant in water deficit, the transcriptional profile of infected plants should simulate that induced by drought stress. In order to validate this hypothesis, we report data relative to expression of genes strongly related to these stresses in two O. europaea $c v$ affected by $X f$, water deficit, or the combination of $X f$ infection and water deficit, representing de facto, the starting point for further investigations on this topic in the olive tree.

Maintenance of water homeostasis is necessary for various biochemical and physiological processes. RWC is considered an essential indicator of water status in plants, representing the balance between water supply and transpiration rate in leaf tissue [39] and is a meaningful determinant of the drought tolerance of plants. In this regard, Cellina cultivar maintains a better water status than that of Leccino cultivar, critical for its physiological functioning and survival under drought. A further decrease in RWC in plants with low tolerance against drought (Leccino) was not observed when subjected to pathogen infection or combined stress, while, in the same conditions, was observed a remarkable decrease in Cellina. In addition, mechanisms producing a synergistic effect between water deficit and infection in trees have been introduced in a study of Dutch elm disease (DED) in Ulmus minor [40]. The severity of symptoms of DED associated with water stress was increased in plants with large vessels more incline to cavitation. Vessel cavitation is considered a determinant process of the wilting of the plant in stress conditions [41]. Again, as reported by Sabella et al. (2018) [24], Xf resistance of olive trees $c v$ Leccino could be influenced by lignin amount in the xylem vessels that limit the bacteria movement and the host invasion by slowing down the disease progression.

The different performance of the two cultivars to individual stress and combined stress also displays in the different gene expression. According to the literature [42], the accumulation of DREB and $D H N$ in plants is associated with drought stress tolerance. In fact, the expression level of these genes in vegetative tissues was generally been found to be higher in drought-tolerant $c v$ Cellina than in susceptible $c v$ Leccino. Other research groups have shown that raising levels of DREB expression increase the expression of downstream target genes encoding late embryogenesis abundant (LEA) proteins, also known as dehydrins (DHNs) [43]. Moreover, both genes were overexpressed also in the presence of $X f$, probably because the bacterium is not recognized by the plant as biotic stress, but rather as abiotic stress related to drought and dehydration allowing the fortification and water loss prevention $[44,45]$. Water channel proteins are known as aquaporins (AQPs) regulate the movement of water and other small molecules across plant vacuolar and plasma membranes; they are associated with plant tolerance of biotic and abiotic stresses. Different responses of AQPs to water deficit stress were found in drought-resistant and drought-sensitive olive cultivars [46]. In our results, mRNA levels in leaves were significantly up-regulated in Cellina, but their expression was lower in Leccino. According to literature, our data indicate that unchanged or down-regulated of aquaporins by water stress may result in reduced cell water permeability and may promote cellular water conservation, demonstrate consequently higher Leccino's resistance to stresses.

One of the inevitable effects of water deficit, caused by abiotic or biotic factors or by a combination of both, is enhanced ROS production in the chloroplasts, the peroxisomes, and the mitochondria, leading to the abnormalities at the cellular level [47]. However, plants are able to deal with such 
stressful conditions through increased synthesis of metabolites, including proline, and antioxidant enzymes [47].

In the present study, the increase in the activities of APX, CAT, and SOD as well as of proline content in Cellina and Leccino cos due to stress conditions were observed (Figure 2; Table 1). The higher levels of APX, CAT, and SOD activities shown in Leccino $c v$ compared to Cellina underline the effectiveness of Leccino's antioxidative enzyme system at protecting the cellular apparatus under individual and combined stress conditions. Furthermore, the higher proline accumulation observed in Leccino olive tree under stresses was accompanied by higher activities of SOD, APX and CAT, suggesting that proline accumulation could activate the antioxidative defense mechanism in Leccino $c v$ as has been suggested by Ahmed et al. (2009) [48] observing intra-specific differences in the water-stressed olive cultivars.

Abiotic and biotic stresses lead to ROS formation and the induction of genes that codify for antioxidant enzymes.

The implication of those genes in furthering plant responses to unfavourable conditions has been well determined in many studies [49,50]. It has been reported that the overexpression of genes encoding antioxidant enzymes origin major tolerance to stress factors in Arabidopsis thaliana [51] and rice [52,53]. Moreover, some data indicate that retaining stable gene expression can confer drought tolerance in plants $[54,55]$. In particular, recently it was evidenced in O. europaea that high concentrations of ROS switch on plant defense signalling pathways in fighting X. fastidiosa infection [56]. This prompted us to examine the role of oxidative stress genes in order to understand the shared mechanism between individual and combined stresses in cultivars considered. As reported by recent studies [27,35] a good performance of photosynthetic apparatus under drought stress is very important also for biotic tolerance of plants, because of influence the antioxidant defense system activity. In particular, we investigated $A P X, C A T, C u / Z n S O D$, and $M n S O D$ genes, commonly belonging to the oxidative stress scavenging system. As reported in Figure 4 the genes in both individual and combined stresses were induced with similar expression patterns within each cultivar. However, a differential expression pattern was observed in the Xf-resistant cultivar Leccino, which shows a higher expression level compared to the susceptible cultivar Cellina. This result appears even more interesting if we consider the lower bacterial content present in Leccino compared to Cellina, suggesting that resistance to $\mathrm{Xf}$ in Leccino is closely related to the higher activity of these genes, regardless of the infection level.

According to Lamb and Dixon (1997) [57], our findings indicate that the susceptibility to drought stress of Leccino provokes an important accumulation of ROS which acts as a secondary messenger in signal transduction and triggers a higher defense response against the pathogen. In fact, also the defense-associated genes were up-regulated in Leccino infected by $X f$ and, as reported by Giampietruzzi et al. (2016) [58], in a special way for the LRR-RLK gene. Also, in our observation, the PR and $L R R-R L K$ genes were not further induced by the additional stress caused by water deficit [17], suggesting that genes can respond to simultaneous stress in a different way and not always in an additive way, as widely reported in the literature [12,32].

\section{Materials and Methods}

\subsection{Field Conditions and Plant Material}

Trials were carried out in summer on O. europaea L. plants, cvs Cellina and Leccino, in productive orchards located in Lecce (Apulia, Southern Italy). Selected plants had previously received the same agronomic practices (with differences only in water management, see following paragraphs) and insect control over 3 years, and phytosanitary treatments had been carried out by the farmers according to EU Decision 2015/789.

We used an experimental design with 24 olive trees, 12 cos Cellina and 12 Leccino with an age ranging from $25-35$ years. The trials were carried out on sandy soils $(76.0 \%$ sand, $19.1 \%$ silt, $4.9 \%$ clay, $1.9 \%$ organic matter). The experimental design included four plant conditions: $X f$-positive trees naturally infected and irrigated (X. fastidiosa, three plants/cultivar), $\mathrm{Xf}$-negative trees and 
subjected to water deficit (Drought, three plants/cultivar), $X f$-positive trees subjected to water deficit (Combined, three plants/cultivar), Xf-negative trees and irrigated (Control, 3 plants/cultivar).

Samples were collected in summer after four weeks of lack of rainfall. For the irrigated plants the water management has predicted schedule irrigation using the water budget approach according to Marra et al., 2016 [59]. In the month before to the sampling, to the well-irrigated thesis of the plants, $3001 /$ tree of water were dispensed.

The $X f$-positive or $X f$-negative plants were assessed by real-time PCR (qPCR) [60]. All presumed $X f$-naturally infected or $X f$-non infected plants were singularly tested each year in the 2016-2018 period. The plants were considered healthy when leaf samples were negative to the $X f$ assay (2016-2018 period). With regards to infected plants, the Cellina and Leccino trees were positive to $X f$ assay since the 2016 test, showing $C t$ values respectively of $24-27$ and $28-30$. The plants selected were monitored for symptoms caused by natural infection of Spilocaea oleagina and Pseudomonas savastanoi pv. savastanoi during the 12 months before sampling. According to Nicolì et al., 2019 [36], the presence of symptoms was scored using a severity scale $(0=$ symptomless, $1=$ symptoms on few branches $(\leq 5)$, 2 = symptoms on several branches $(>5)$, and $3=$ symptoms uniformly distributed throughout the canopy). In addition, diagnostic tests (real-time PCR) were carried out according to the literature for Botryosphaeria dothidea [61], Colletotrichum spp., C. acutatum and C. gloeosporioide [62], Diplodia seriata [63], Phaeomoniella chlamydospore [64], Phaeoacremonium aleophilum and P. parasiticum [65,66], Phytophthora spp. [67], Verticillium dahlia [68].

In order to analyze homogeneous trees, both Xf-positive and negative plants were selected according to lower severity $(=1)$ for Pseudomonas savastanoi pv. savastanoi and Spilocaea oleagina and negative to every other diagnostic test but for $X f$.

\subsection{Relative Water Content Measurement}

Relative water content (RWC) was carried out following the procedure proposed by Barrs and Weatherley (1962) [69] on fully expanded leaves of similar age, divided into blocks of ten leaves each per treatment. Leaves were excised, weighed fresh (FW) and placed in distilled water in the dark for $24 \mathrm{~h}$ to rehydrate. The turgid leaf weight (TW) was measured and then leaves were dried at $80^{\circ} \mathrm{C}$ for $48 \mathrm{~h}$ and dry weight (DW) was determined. The RWC was calculated as:

$$
\mathrm{RWC}=[(\mathrm{FW}-\mathrm{DW}) /(\mathrm{TW}-\mathrm{DW})] \times 100
$$

\subsection{Free Proline Determination}

Approximately $0.5 \mathrm{~g}$ of powder plant material from control and stressed plants was homogenized in 3\% aqueous sulfosalicylic acid. Free proline content was determined according to Bates et al. (1973) [70]. Proline concentration was calculated using L-proline for the standard curve and reported as $\mu \mathrm{mol} \mathrm{g} \mathrm{FW}^{-1}$.

\subsection{Antioxidant Enzymes Determinations}

Olive leaves $(0.5 \mathrm{~g})$ were ground with pestle and mortar in liquid nitrogen. Then, the powder transferred into precooled tubes and $1 \mathrm{~mL}$ of $50 \mathrm{mM}$ potassium phosphate buffer ( $\mathrm{pH} 7.0$ ), containing $1 \mathrm{mM}$ EDTA and $4 \%$ PVPP was subsequently added to tubes. The homogenate was centrifuged at $15,000 \mathrm{~g}$ for $20 \mathrm{~min}$ at $4{ }^{\circ} \mathrm{C}$.

The supernatants were collected and used for assays of enzymatic activities. The ascorbate peroxidase (APX, EC1.11.1.11), catalase (CAT, EC 1.11.1.6) and superoxide dismutase (SOD, EC 1.15.1.1) activities were determined according to the method of Giannopolitis and Ries (1977) [71], Chance and Maehly, (1995) [72], and Nakano and Asada (1981) [73], respectively. The values of enzyme activities were expressed as units per $\mathrm{mg}^{-1}$ dry weight.

\subsection{Total RNA Isolation, cDNA Synthesis, and Real-Time PCR Analysis}

Total RNA was extracted from leaf samples using TRIzol ${ }^{\circledR}$ (Promega) according to the protocol of the manufacturer. RNA samples were deal with DNase I (Promega) before that their absorbance 
was read at 260 and $280 \mathrm{~nm}$ to define RNA concentration and purity. cDNA synthesis was performed using TaqMan ${ }^{\circledR}$ Reverse Transcription Reagents (Applied Biosystems, Foster City, USA) according to the manufacturer's instruction, with oligo (dT) 18 as a primer. The RT- PCR was carried out using SYBR Green fluorescent detection in a Real-Time PCR thermal cycler (ABI PRISM 7900 Sequence Detection System, Applied Biosystems, Foster City, CA, USA). The PCR program was: 2 min at $50^{\circ} \mathrm{C}$ and $10 \mathrm{~min}$ at $95^{\circ} \mathrm{C}$, followed by 45 cycles of $95^{\circ} \mathrm{C}$ for $15 \mathrm{~s}$ and $60^{\circ} \mathrm{C}$ for $1 \mathrm{~min}$. Melting curve analysis was performed after PCR to evaluate the presence of non-specific PCR products and primer dimers. Three biological and three technical replicates were analyzed. The used primers were retrieved from the literature or designed with the software Primer Express Software 3.0 on the mRNA sequences deposited in GenBank. The primers were designed on the genes related to oxidative stress such as superoxide dismutase ( $\mathrm{Cu} / \mathrm{Zn} S O D$ and $M n S O D)$, catalase (CAT), ascorbate peroxidase $(A P X)$. The genes related to pathogen stress, such as leucine rich repeats-receptors like kinase $(L R R-R L K)$ [58] and pathogenesis-related protein 1-like (PR). The genes related to drought responses such as aquaporin (PIP2.1) [44], dehydration responsive element binding (DREB) and dehydrin (DHN). To standardize the results the relative abundance of ubiquitin gene (UBQ) was used as the internal standard (Table 2). Relative gene expression levels were calculated with the $\log _{2} 2^{-\Delta \Delta C t}$ method $[74,75]$. The efficiency of the target amplification was evaluated for each primer pairs and the corresponding value was used to calculate the fold changes $(F C)$ with the following formula: $F C=(1+E)^{-\Delta \Delta C t}$, where $\Delta \Delta \mathrm{Ct}=\left(\mathrm{Ct}_{\text {target }}-\mathrm{Ct}_{\mathrm{UBQ}}\right)_{\text {Treatment }}-\left(\mathrm{Ct}_{\text {target }}-\mathrm{Ct}_{\mathrm{UBQ}}\right)_{\text {Control }}$. 
Table 2. Primers used to evaluate the expression of genes involved in drought stress, stress induced by Xylella fastidiosa and combined stresses in Olea europaea L. Cellina di Nardò and Leccino.

\begin{tabular}{|c|c|c|c|c|}
\hline Functional Categories and Genes & Abbr. & Primer & Sequence $5^{\prime}-3^{\prime}$ & GeneBank \\
\hline \multicolumn{5}{|l|}{ ROS scavenging activity genes related } \\
\hline \multirow{2}{*}{ Ascorbate Peroxidase } & \multirow{2}{*}{ APX } & OeAPXF & CAAAAACTGCGCCССТATAA & \multirow{2}{*}{ XM023040324.1 } \\
\hline & & OeAPXR & ACAGCAACAACACCAGCAAG & \\
\hline \multirow{2}{*}{ Catalase } & \multirow[b]{2}{*}{ CAT } & OeCATF & GGATCCAGCCAGACAAGAGA & \multirow{2}{*}{ JQ429793 } \\
\hline & & OeCATR & TTGGCCTTACATTGAGACGA & \\
\hline \multirow{2}{*}{ Manganese Superoxide Dismutase } & \multirow{2}{*}{ MnSOD } & OeMnSODF & CTCCTGTTCGTGAAGGTGGT & \multirow{2}{*}{ AF427107 } \\
\hline & & OeMnSODR & GTGTCCAGACCAAGCCAAAT & \\
\hline \multirow{2}{*}{ Copper/Zinc Superoxide Dismutase } & \multirow{2}{*}{$\mathrm{Cu} / \mathrm{ZnSOD}$} & $\mathrm{OeCu} / \mathrm{ZnSODF}$ & CCATGCTGGTGATCTTGGTA & \multirow{2}{*}{ AF191342 } \\
\hline & & $\mathrm{OeCu} / \mathrm{ZnSODR}$ & CAGTTCATGACCACCCCTTC & \\
\hline \multicolumn{5}{|l|}{ Pathogen genes related } \\
\hline \multirow{2}{*}{ Leucine Rich Repeats } & \multirow{2}{*}{ LRR-RLK } & OeLRRF & CAACACAAGGCTTTTGGGACTT & \multirow{2}{*}{ XP_006367556.1 * } \\
\hline & & OeLRRR & TGTCATTGGTGCTTGTTGGT & \\
\hline \multirow{2}{*}{ Pathogenesis Protein Related } & \multirow{2}{*}{ PR } & OePRF & AACAAGGCTCGTGCAGAAGT & \multirow[b]{2}{*}{ XM023013713 } \\
\hline & & OePRR & TCGACCCATGATCATAGCAA & \\
\hline \multicolumn{5}{|l|}{ Water deficit genes related } \\
\hline \multirow{2}{*}{ Aquaporine } & \multirow{2}{*}{ PIP2.1 } & OePIP2.1F & TCTCGGGCCCTTGTTTTAGA & \multirow{2}{*}{ DQ202709 } \\
\hline & & OePIP2.1R & AAAGAGAGGCCAGCAACCG & \\
\hline \multirow{2}{*}{$\begin{array}{c}\text { Dehydration responsive element } \\
\text { binding }\end{array}$} & \multirow{2}{*}{ DREB } & OeDREBF & ACATGTTCTCCGCTCAGCTT & \multirow{2}{*}{ EF635424.1 } \\
\hline & & OeDREBR & GTGCCTCGTCTCCTTGAAAA & \\
\hline \multirow[t]{2}{*}{ Dehydrin } & \multirow{2}{*}{$\mathrm{DHN}$} & OeDHNF & GGTTTGAAGGGGAAGGTTTC & \multirow{2}{*}{ KR349290.1 } \\
\hline & & OeDHNR & СTTCCTCAGCCTTCTTGTGG & \\
\hline \multicolumn{5}{|l|}{ Reference gene } \\
\hline Polyubiquitin & UBQ & OeUBQF & GGTGGCCTCTAAATGTTCTTCTACTG & AF429430 * \\
\hline & & OeUBQR & CACACAGACTTCATTAGAAAGACAATCA & \\
\hline
\end{tabular}

* LRR-RLK and UBQ primers were retrieved from Giampietruzzi et al., 2016 [58]. 


\subsection{Statistical Analysis}

All data were reported as the mean $\pm \mathrm{SD}$ with at least three replications for each leaf olive sample. A two-way ANOVA with the replicates of each measure was carried out on RWC data using cultivar and stress conditions as main factors. The data related to gene expression level for each stress (individual and combined stresses) were subjected to one-way ANOVA analysis, followed by Tukey-HSD (honestly significant difference) post hoc test $(p<0.05)$. Also, the statistical analysis was performing using multiple $t$-tests (FDR $=5 \%$ ) to under light the differences between cultivars for each gene and for each stress. Statistical analyses were performed using GraphPad software, version 6.01.

\section{Conclusions}

The expertise of how abiotic environmental factors influence plant resistance to pathogens and how systems specifically elaborate the response to combined abiotic and biotic stress for disease management is important to breeding programs aimed at improving $X f$ resistance in O. europaea cultivars also in the forecast of future climate changes. In this work, we hypothesize that the resistance of Leccino to Xf could be related to its lower resistance to water stress, that could lead to the activation of alternative defense pathways which support the plant in $X f$ response, as widely discussed by Ramegowda et al., 2013 [18] about drought-pathogen stress interactions in plants. Due to the critical status of $X f$ epidemy in Salento, here we report urgently the first evidence about host's transcriptional responses of drought-related genes to natural infection according to water management practices commonly carried out in the area. However, the transcription of further genes, the correlation of gene expression with enzymatic activities and trials with artificially inoculated plants submitted to different levels of water deficit grown in controlled environment should drive further research to confirm this evidence and improve the understanding of the molecular basis of stress resistance.

Author Contributions: A.L., M.D.P. and M.V. designed the research. E.S., C.N., F.N. did the sampling. M.D.P., M.V., A.A., P.R. and E.N. performed gene expression analysis. M.D.P. and C.N. performed Relative Water Content Analysis. E.S., F.N. and I.B. performed health analysis. A.L., M.D.P., M.V. analyzed the data and prepared figures and tables. M.D.P. and M.V. wrote the manuscript. A.L., A.M. and L.D.B. critically reviewed the manuscript. All authors read and approved the final manuscript.

Funding: This research received no external funding.

Acknowledgments: We are grateful to Raffaele Mancarella to olive orchards management.

Conflicts of Interest: The authors declare no conflict of interest.

\section{References}

1. Abuqamar, S.; Luo, H.; Laluk, K.; Mickelbart, M.V.; Mengiste, T. Crosstalk between biotic and abiotic stress responses in tomato is mediated by the AIM1 transcription factor. Plant J. 2009, 58, 347-360. [CrossRef] [PubMed]

2. Mengiste, T.; Chen, X.; Salmeron, J.; Dietrich, R. The Botrytis susceptible1 gene encodes an R2R3MYB transcription factor protein that is required for biotic and abiotic stress responses in Arabidopsis. Plant Cell 2003, 15, 2551-2565. [CrossRef] [PubMed]

3. Suzuki, N.; Rizhsky, L.; Liang, H.; Shuman, J.; Shulaev, V.; Mittler, R. Enhanced tolerance to environmental stress in transgenic plants expressing the transcriptional coactivator multiprotein bridging factor 1c. Plant Physiol. 2005, 139, 1313-1322. [CrossRef] [PubMed]

4. Narsai, R.; Wang, C.; Chen, J.; Wu, J.; Shou, H.; Whelan, J. Antagonistic, overlapping and distinct responses to biotic stress in rice (Oryza sativa) and interactions with abiotic stress. BMC Genomics. 2013, 14, 93. [CrossRef] [PubMed]

5. Shaik, R.; Ramakrishna, W. Genes and co-expression modules common to drought and bacterial stress responses in Arabidopsis and rice. PLoS ONE 2013, 8, 77261. [CrossRef] [PubMed]

6. Shaik, R.; Ramakrishna, W. Machine learning approaches distinguish multiple stress conditions using stress-responsive genes and identify candidate genes for broad resistance in rice. Plant Physiol. 2014, 164, 481-495. [CrossRef] 
7. Sharma, R.; Vleesschauwer, D.D.; Sharma, M.K.; Ronald, P.C. Recent advances in dissecting stress-regulatory crosstalk in rice. Mol. Plant 2013, 6, 250-260. [CrossRef]

8. Atkinson, N.J.; Lilley, C.J.; Urwin, P.E. Identification of genes involved in the response of Arabidopsis to simultaneous biotic and abiotic stresses. Plant Physiol. 2013, 162, 2028-2041. [CrossRef]

9. Bostock, R.M.; Pye, M.F.; Roubtsova, T.V. Predisposition in plant disease: Exploiting the nexus in abiotic and biotic stress perception and response. Annu. Rev. Phytopathol. 2014, 52, 517-549. [CrossRef]

10. Kissoudis, C.; Van de Wiel, C.; Visser, R.G.F.; Van Der Linden, G. Enhancing crop resilience to combined abiotic and biotic stress through the dissection of physiological and molecular crosstalk. Front. Plant Sci. 2014, 5, 207.

11. Mittler, R. Abiotic stress, the field environment and stress combination. Trends Plant Sci. 2006, 11, 15-19. [CrossRef] [PubMed]

12. Pandey, P.; Ramegowda, V.; Senthil-Kumar, M. Shared and unique responses of plants to multiple individual stresses and stress combinations: Physiological and molecular mechanisms. Front. Plant Sci. 2015, 6, 723. [CrossRef] [PubMed]

13. Prasch, C.M.; Sonnewald, U. Signaling events in plants: Stress factors in combination change the picture. Environ. Exp. Bot. 2015, 114, 4-14. [CrossRef]

14. Prasch, C.M.; Sonnewald, U. Simultaneous application of heat, drought, and virus to Arabidopsis plants reveals significant shifts in signaling networks. Plant Physiol. 2013, 162, 1849-1866. [CrossRef] [PubMed]

15. Rasmussen, S.; Barah, P.; Suarez-Rodriguez, M.C.; Bressendorf, S.; Friis, P.; Costantino, P. Transcriptome responses to combinations of stresses in Arabidopsis. Plant Physiol. 2013, 161, 1783-1794. [CrossRef] [PubMed]

16. Mattson, W.J.; Haack, R.A. The role of drought stress in provoking outbreaks of phytophagous insects. In Insect Outbreaks; Barbosa, P., Schultz, J.C., Eds.; Academic Press: New York, NY, USA, 1987; pp. 365-407.

17. Choi, H.K.; Iandolino, A.; Silva, F.G.; Cook, D.R. Water deficit modulates the response of Vitis vinifera to the Pierce's disease pathogen Xylella fastidiosa. Mol. Plant-Microbe Interact. 2013, 26, 643-657. [CrossRef]

18. Ramegowda, V.; Senthil-Kumar, M.; Ishiga, Y.; Kaundal, A.; Udayakumar, M.; Mysore, K.S. Drought stress acclimation imparts tolerance to Sclerotinia sclerotirum and Pseudomonas syringae in Nicotiana benthamiana. Int. J. Mol. Sci. 2013, 14, 9497-9513. [CrossRef]

19. Gupta, A.; Sarkar, A.K.; Senthil-Kumar, M. Global transcriptional analysis reveals unique and shared response in Arabidopsis thaliana exposed to combined drought and pathogen stress. Front. Plant Sci. 2016, 7, 686. [CrossRef]

20. Mittler, R.; Vanderauwera, S.; Gollery, M.; Van Breusegem, F. The reactive oxygen gene network in plants. Trends Plant Sci. 2004, 9, 490-498. [CrossRef]

21. Chiappetta, A.; Muto, A.; Bruno, L.; Woloszynska, M.; Vanlijsebettens, M.; Bitonti, M.B. A dehydrin gene isolated from feral olive enhances drought tolerance in Arabidopsis transgenic plants. Front. Plant Sci. 2015, 6, 392. [CrossRef]

22. Saponari, M.; Boscia, D.; Nigro, F.; Martelli, G.P. Identification of DNA sequences related to Xylella fastidiosa in oleander, almond and olive trees exhibiting leaf scorch symptoms in Apulia (southern Italy). J. Plant Pathol. 2013, 95, 668 .

23. Luvisi, A.; Aprile, A.; Sabella, E.; Vergine, M.; Nicolì, F.; Nutricati, E.; Miceli, A.; Negro, C.; De Bellis, L. Xylella fastidiosa subsp. pauca (CoDiRO strain) infection in four olive (Olea europaea L.) cultivars: Profile of phenolic compounds in leaves and progression of leaf scorch symptoms. Phytopathol. Mediterr. 2017, 56, 259-273.

24. Sabella, E.; Luvisi, A.; Aprile, A.; Negro, C.; Vergine, M.; Nicolì, F.; Miceli, A.; De Bellis, L. Xylella fastidiosa induces differential expression of lignification related-genes and lignin accumulation in tolerant olive trees cv. Leccino. J. Plant Physiol. 2018, 220, 60-68. [CrossRef] [PubMed]

25. Loconsole, G.; Saponari, M.; Boscia, D.; D’Attoma, G.; Morelli, M.; Martelli, G.; Almeida, R.P.P. Intercepted isolates of Xylella fastidiosa in Europe reveal novel genetic diversity. Eur. J. Plant Pathol. 2016, 146, 85-94. [CrossRef]

26. Cardinale, M.; Luvisi, A.; Meyer, J.B.; Sabella, E.; De Bellis, L.; Cruz, A.C.; Ampatzidis, Y.; Cherubini, P. Specific Fluorescence in Situ Hybridization (FISH) Test to Highlight Colonization of Xylem Vessels by Xylella fastidiosa in Naturally Infected Olive Trees (Olea europaea L.). Front. Plant Sci. 2018, 9, 431. [CrossRef] 
27. Dąbrowski, P.; Baczewska-Dabrowska, A.H.; Kalaji, H.M.; Goltsev, V.; Paunov, M.; Rapacz, M.; Wójcik-Jagła, M.; Pawluśkiewicz, B.; Bąba, W.; Brestic, M. Exploration of chlorophyll a fluorescence and plant gas exchange parameters as indicators of drought tolerance in perennial ryegrass. Sensors 2019, 19, 2736. [CrossRef]

28. Bosso, L.; Febbraro, M.; Cristinzio, G.; Zoina, A.; Russo, D. Shedding light on the effects of climate change on the potential distribution of Xylella fastidiosa. Biol. Invasions 2016, 18, 1759-1768. [CrossRef]

29. Keller, R.P.; Lodge, D.M.; Finnoff, D.C. Risk assessment for invasive species produces net bioeconomic benefits. Proc. Natl. Acad. Sci. USA 2007, 104, 203-207. [CrossRef]

30. IPCC. Principles Governing IPCC Work. Intergovernmental Panel on Climate Change (IPCC): Geneva, Switzerland, 2013; Volume 2, Available online: https:/www.ipcc.ch/site/assets/uploads/sites/2/2019/05/SR15_ Chapter1_Low_Res.pdf (accessed on 21 October 2019).

31. Ramegowda, V.; Senthil-Kumar, M.; Udayakumar, M.; Kirankumar, S.M. A high-throughput virus induced gene silencing protocol identifies genes involved in multistress tolerance. BMC Plant Biol. 2013, 13, 193.

32. Choudhury, F.K.; Rivero, R.M.; Blumwald, E.; Mittler, R. Reactive oxygen species, abiotic stress and stress combination. Plant J. 2017, 90, 856-867. [CrossRef]

33. Zarattini, M.; Forlani, G. Toward unveiling the mechanisms for transcriptional regulation of proline biosynthesis in the plant cell response to biotic and abiotic stress conditions. Front. Plant Sci. 2017, 8, 927. [CrossRef] [PubMed]

34. Cai, Z.; Riedel, H.; Saw, N.M.M.T.; Kütük, O.; Mewis, I.; Jäger, H.; Knorr, D.; Smetanska, I. Effects of pulsed electric field on secondary metabolism of Vitis vinifera L. cv. Gamay Fréaux suspension culture and exudates. Appl. Biochem. Biotechnol. 2011, 164, 443-453. [CrossRef] [PubMed]

35. Mao, H.; Chen, M.; Su, Y.; Wu, N.; Yuan, M.; Yuan, S.; Brestic, M.; Zivcak, M.; Zhang, H.; Chen, Y. Comparison on photosynthesis and antioxidant defense systems in wheat with different ploidy levels and octoploid triticale. Int. J. Mol. Sci. 2018, 19, 3006. [CrossRef] [PubMed]

36. Nicolì, F.; Negro, C.; Nutricati, E.; Vergine, M.; Aprile, A.; Sabella, E.; Damiano, G.; De Bellis, L.; Luvisi, A. Accumulation of azelaic acid in Xylella fastidiosa-infected olive trees: A mobile metabolite for health screening. Phytopathology 2018, 109, 318-325. [CrossRef] [PubMed]

37. Goodwin, P.H.; DeVay, J.E.; Meredith, C.P. Roles of water stress and phytotoxins in the development of Pierce's disease of the grapevine. Physiol. Mol. Plant Pathol. 1988, 32, 1-15. [CrossRef]

38. Hsiao, T.C. Plant responses to water stress. Annu. Rev. Plant Physiol. 1973, 24, 519-570. [CrossRef]

39. Lugojan, C.; Ciulca, S. Evaluation of relative water content in winter wheat. J. Hortic. For. Biotechnol. 2011, $15,173-177$.

40. Solla, A.; Gil, L. Influence of water stress on Dutch elm disease symptoms in Ulmus minor. Can. J. Bot. 2002, 80, 810-817. [CrossRef]

41. Sabella, E.; Aprile, A.; Genga, A.; Siciliano, T.; Nutricati, E.; Nicolì, F.; Vergine, M.; Negro, C.; De Bellis, L.; Luvisi, A. Xylem cavitation susceptibility and refilling mechanisms in olive trees infected by Xylella fastidiosa. Sci. Rep. 2019, 9, 9602. [CrossRef]

42. Hu, L.; Wang, Z.; Du, H.; Huang, B. Differential accumulation of dehydrins in response to water stress for hybrid and common bermudagrass genotypes differing in drought tolerance. J. Plant Physiol. 2010, 167, 103-110. [CrossRef]

43. Battaglia, M.; Olvera-Carrillo Garciarrubio, A.; Campos, F.; Covarrubias, A.A. The enigmatic LEA proteins and other hydrophilins. Plant Physiol. 2008, 148, 6-24. [CrossRef] [PubMed]

44. Secchi, F.; Lovisolo, C.; Schubert, A. Expression of OePIP2.1 aquaporin gene and water relations of Olea europaea twigs during drought stress and recovery. Ann. Appl. Biol. 2007, 150, 163-167. [CrossRef]

45. Rapicavoli, J.N.; Blanco-Ulate, B.; Muszyński, A.; Figueroa-Balderas, R.; Morales-Cruz, A.; Azadi, P.; Dobruchowska, J.M.; Castro, C.; Cantu, D.; Roper, M.C. Lipopolysaccharide O-antigen delays plant innate immune recognition of Xylella fastidiosa. Nat. Commun. 2018, 9, 390. [CrossRef] [PubMed]

46. Roper, C.; Castro, C.; Ingel, B. Xylella fastidiosa: Bacterial parasitism with hallmarks of commensalism. Curr. Opin. Plant Biol. 2019, 50, 140-147. [CrossRef] [PubMed]

47. Hayat, S.; Yadav, S.; Wani, A.S.; Irfan, M.; Alyemini, M.N.; Ahmad, A. Impact of sodium nitroprusside on nitrate reductase, proline and antioxidant system in Solanum lycopersicum under salinity stress. Hort. Environ. Biotechnol. 2012, 53, 362-367. [CrossRef] 
48. Ben Ahmed, C.; Ben Rouinab, B.; Sensoyc, S.; Boukhrisa, M.; Ben Abdallah, F. Changes in gas exchange, proline accumulation and antioxidative enzyme activities in three olive cultivars under contrasting water availability regimes. Environ. Exp. Bot. 2009, 67, 345-352. [CrossRef]

49. Xu, F.J.; Jin, C.W.; Liu, W.J.; Zhang, Y.S.; Lin, X.Y. Pretreatment with $\mathrm{H}_{2} \mathrm{O}_{2}$ alleviates aluminum-induced oxidative stress in wheat seedlings. J. Integr. Plant Biol. 2011, 53, 44-53. [CrossRef]

50. Zhang, Y.; Wang, X.; Li, Y.; Wu, L.; Zhou, H.; Zhang, G.; Ma, Z. Ectopic expression of a novel Ser/Thr protein kinase from cotton (Gossypium barbadense), enhances resistance to Verticillium dahliae infection and oxidative stress in Arabidopsis. Plant Cell Rep. 2013, 32, 1703-1713. [CrossRef]

51. Rossel, J.B.; Walter, P.B.; Hendrickson, L.; Chow, W.S.; Poole, A.; Mullineaux, P.M.; Pogson, B.J. A mutation affecting Ascorbate peroxidase 2 gene expression reveals a link between responses to high light and drought tolerance. Plant Cell Environ. 2006, 29, 269-281. [CrossRef]

52. Prashanth, S.R.; Sadhasivam, V.; Parida, A. Over expression of cytosolic copper/zinc superoxide dismutase from a mangrove plant Avicennia marina in indica rice var Pusa Basmati-1 confers abiotic stress tolerance. Transgenic Res. 2008, 17, 281-291. [CrossRef]

53. Badawi, G.H.; Kawano, N.; Yamauchi, Y.; Shimada, E.; Sasaki, R.; Kubo, A.; Tanaka, K. Over-expression of ascorbate peroxidase in tobacco chloroplasts enhances the tolerance to salt stress and water deficit. Physiol. Plant. 2004, 121, 231-238. [CrossRef] [PubMed]

54. Bian, S.; Jiang, Y. Reactive oxygen species, antioxidant enzyme activities and gene expression patterns in leaves and roots of Kentucky bluegrass in response to drought stress and recovery. Sci. Hort. 2009, 120, 264-270. [CrossRef]

55. Jiang, H.W.; Liu, M.J.; Chen, I.C.; Huang, C.H.; Chao, L.Y.; Hsieh, H.L. A glutathione S-transferase regulated by light and hormones participates in the modulation of Arabidopsis seedling development. Plant Physiol. 2010, 154, 1646-1658. [CrossRef] [PubMed]

56. Novelli, S.; Gismondi, A.; Di Marco, G.; Canuti, L.; Nanni, V.; Caninelli, A. Plant defense factors involved in Olea europaea resistance against Xylella fastidiosa infection. J. Plant Res. 2019, 132, 439-455. [CrossRef] [PubMed]

57. Lamb, C.; Dixon, R. The oxidative burst in plant disease resistance. Annu. Rev. Plant. Physiol. Plant Mol. Biol. 1997, 48, 251-275. [CrossRef] [PubMed]

58. Giampetruzzi, A.; Morelli, M.; Saponari, M.; Loconsole, G.; Chiumenti, M.; Boscia, D.; Savino, V.N.; Martelli, G.P.; Saldarelli, P. Transcriptome profiling of two olive cultivars in response to infection by the CoDiRO strain of Xylella fastidiosa subsp. pauca. BMC Genomics 2016, 1, 475. [CrossRef]

59. Marra, F.P.; Marino, G.; Marchese, A.; Caruso, T. Effects of different irrigation regimes on a super-high-density olive grove $c v$. "Arbequina": Vegetative growth, productivity and polyphenol content of the oil. Irrig. Sci. 2016, 34, 313-325. [CrossRef]

60. Harper, S.J.; Ward, L.I.; Clover, G.R.G. Development of LAMP and Real-Time PCR Methods for the rapid detection of Xylella fastidiosa for quarantine and field applications. Phytopatology 2010, 100, 1282-1288. [CrossRef]

61. Romanazzi, G.; Murolo, S.; Pizzichini, L.; Nardi, S. Esca in young and mature vineyards: And molecular diagnosis of the associated fungi. Eur. J. Plant Pathol. 2009, 125, 277-290. [CrossRef]

62. Garrido, C.; Carbú, M.; Fernández-Acero, F.J.; Boonha, N.; Colyer, A.; Cantoral, J.M.; Budge, G. Development of protocols for detection of Colletotrichum acutatum and monitoring of strawberry anthracnose using qPCR. Plant Pathol. 2009, 58, 43-51. [CrossRef]

63. Martín, M.T.; Cuesta, M.J.; Martín, L. Development of SCAR primers for PCR assay to detect Diplodia seriata. Int. Sch. Res. Not. 2014. [CrossRef] [PubMed]

64. Martín, M.T.; Cobos, R.; Martín, L.; López-Enríquez, L. qPCR Detection of Phaeomoniella chlamydospora and Phaeoacremonium aleophilum. Appl. Environ. Microb. 2012, 78, 3985-3991. [CrossRef] [PubMed]

65. Aroca, A.; Raposo, R.; Lunello, P. A biomarker for the identification of four Phaeoacremonium species using the $\beta$-tubulin gene as the target sequence. Appl. Microbiol. Biot. 2008, 80, 1131-1140. [CrossRef] [PubMed]

66. Carlucci, A.; Lops, F.; Marchi, G.; Mugnai, L.; Surico, G. Has Xylella fastidiosa "Chosen" Olive Trees to Establish in the Mediterranean Basin? Phytopathol. Mediterr. 2013, 52, 541-544.

67. Drenth, A.; Wagels, G.; Smith, B.; Sendall, B.; O’Dwyer, C.; Irvine, G.; Irwin, J.A.G. Development of a DNA-based method for detection and identification of Phytophthora species. Australas. Plant. Path. 2006, 35, 147-159. [CrossRef] 
68. Bilodeau, G.J.; Koike, S.T.; Uribe, P.; Martin, F.N. Development of an assay for rapid detection and quantification of Verticillium dahliae in soil. Phytopathology 2012, 102, 331-343. [CrossRef]

69. Barrs, H.D.; Weatherley, P.E. A re-examination of the relative turgidity technique for estimanting water deficits in leaves. Austral. J. Biol. Sci. 1962, 15, 413-428. [CrossRef]

70. Bates, L.S.; Waldren, R.P.; Teare, I.D. Rapid determination of free proline for water-stress studies. Plant Soil. 1973, 39, 205. [CrossRef]

71. Giannopolitis, C.N.; Rise, S.K. Superoxide dismutases. I. Occurrence in higher plants. Plant Physiol. 1977, 59, 304-309. [CrossRef]

72. Nakano, Y.; Asada, K. Spinach chloroplasts scavenge hydrogenperoxide on illumination. Plant Cell Physiol. 1980, 21, 1295-1307. [CrossRef]

73. Chance, B.; Maehly, S.K. Assay of catalase and peroxidase. Methods Enzymol. 1955, 2, 764-775.

74. Livak, K.J.; Schmittgen, T.D. Analysis of relative gene expression data using real-time quantitative PCR and the $2^{-\Delta \Delta C T}$ method. Methods 2001, 25, 402-408. [CrossRef] [PubMed]

75. Quackenbush, J. Microarray data normalization and transformation. Nat. Genet. 2002, 32, 496-501. [CrossRef] [PubMed]

(C) 2019 by the authors. Licensee MDPI, Basel, Switzerland. This article is an open access article distributed under the terms and conditions of the Creative Commons Attribution (CC BY) license (http://creativecommons.org/licenses/by/4.0/). 